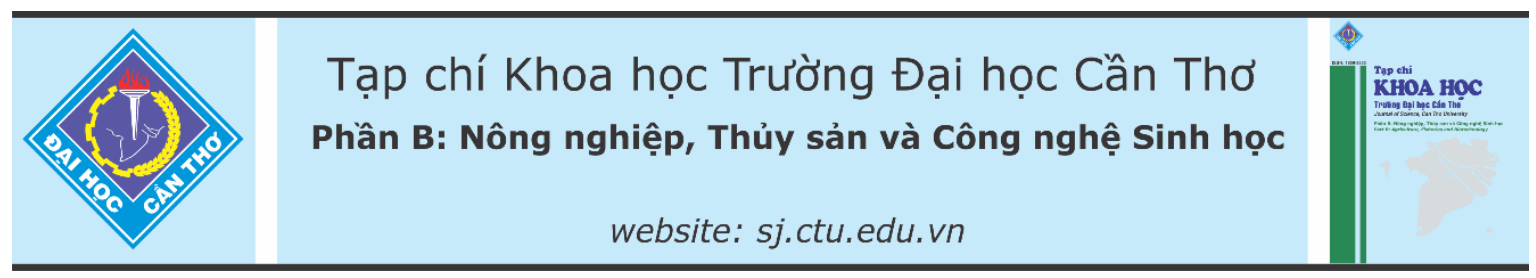

DOI:10.22144/ctu.jvn.2021.157

\title{
NGHIÊN CÚU MỘT SỐ ĐẶC ĐIỂM BỆNH LÝ LÂM SÀNG BỆNH SÁN LÁ GẢN NHỎ TRÊN CHÓ
}

\author{
Nguyễn Văn Thoại ${ }^{1}$, Nguyễn Đức Tân ${ }^{1}$, Lê Đức Quyết ${ }^{1}$, Lê Hứa Ngọc Lực ${ }^{1}$, Huỳnh Vũ Vỹ ${ }^{1 *}$ và \\ Trương Hoàng Phương ${ }^{2}$ \\ ${ }^{I}$ Phân viện Thú y miền Trung \\ ${ }^{2}$ Sở Khoa họ và Công nghệ Cần Tho \\ *Nguời chịu trách nhiệm về bài viết: Huỳnh Vũ Vỹ (email: huynhvuvy@gmail.com)
}

\section{Thông tin chung:}

Ngày nhận bài: 29/03/2021

Ngày nhận bài sủa: 29/07/2021

Ngày duyệt đăng: 29/10/2021

Title:

Study on some characteristics of clinical pathology of

Opisthorchiasis or

Clonorchiasis in dogs

\section{Tù khóa:}

Bệnh sán lá gan nhỏ, chó, triệu chứng lâm sàng

\section{Keywords:}

Clinical symptoms, dogs,

Opisthorchiasis or

Clonorchiasis

\begin{abstract}
The purpose of this study was to determine clinical pathology of Opisthorchiasis or Clonorchiasis in dogs by experimental infection. Research results show that clinical pathology in dogs were mild in the early stage and severe in the later stage, some clinical symptoms including mild fever, ruffled, tiredness, eating less, weakness, bloating, diarrhea or constipation and death. Gross lesion: The body was thin; the abdominal cavity was watery; hepatitis, congestion and hemorrhage, the face of the liver was inflaming and there were lots of necroses; the gallbladder was inflaming 2-3 times; the stomach contained some undigested foods; the colon was inflamed. Histopathological examination: In the liver, red blood cells were filled the vascular lumen, infiltration of inflammation cells, fatty degeneration of hepatocytes and vacuole degeneration; hepatocytes were necrotic and pink colour when they were stained with Hematoxylin and Eosin.
\end{abstract}

\section{TÓM TĂT}

Mục tiêu của nghiên cứu là xác định được bệnh lý lâm sàng chó bị bệnh sán lá gan nhỏ trong gây nhiễm thực nghiệm. Kết quả nghiên cứu cho thấy, bệnh lý lâm sàng chó thuờng nhẹ ở giai đoạn đầu và nặng ở giai đoạn sau bị bệnh. Một số triệu chúng nhu sốt nhẹ, lông xù, mệt mỏi, giảm ăn, gầy yếu, bụng chuoóng, tiêu chảy hoặc táo bón và chết. Bệnh tích đại thể: xác con vật gầy, xoang bung tích nước, gan viêm, sung huyết và xuất huyết, mặt gan sung và có nhiều đám hoại tử, túi mật sung 2-3 lần, dạ dày chứa nhiều thức ăn không tiêu, ruột kết viêm. Bệnh tích vi thể: ở gan, hồng cầu tràn ngập lòng mạch quản, thâm nhiếm tế bào viêm, tế bào gan thoái hóa mõ và thoái hóa không bào, tế bào gan hoại tử bắt màu hồng đều.
Campuchia và Việt Nam. Bệnh này đã được nghiên cứu rộng rãi ở Thái Lan, nơi được coi là trung tâm về dịch tễ của loài Opisthorchis viverrini, ước tính có khoảng 6 triệu người bị nhiễm sán này (Havelaar et al., 2015). Ở Việt Nam, sán lá gan nhỏ ở người phân bố trên 24 tỉnh/thành phố, trong đó có 15 tỉnh 
phía Bắc và 10 tỉnh miền Trung-Tây Nguyên với tỷ lệ nhiễm từ 0,2-37\% (Nguyễn Văn Đề \& Lê Thanh Hòa, 2007). Vấn đề dịch tễ học về tình hình nhiễm sán lá gan nhỏ trên người tại một số tỉnh miền Bắc, miền Trung đã được đề cập, đặc điểm hình thái học, sinh học phân tử của sán lá gan nhỏ trên người đã có nhiều nghiên cứu (Bùi Văn Tuấn và ctv., 2017; Nguyễn Mạnh Hùng và ctv., 2013; Nguyễn Văn Chương và ctv., 2009; Tran et al., 2019...). Tuy nhiên, các dữ liệu về bệnh sán lá gan nhỏ trên động vật vẫn còn thiếu, đặc biệt là những nghiên cứu về bệnh lý lâm sàng. Vì vậy, việc nghiên cứu một số đặc điểm bệnh lý lâm sàng bệnh sán lá gan nhỏ trên chó là rất cần thiết, nhằm xác định các dấu hiệu lý bệnh sán lá gan nhỏ, đồng thời hỗ trợ trong công tác chẩn đoán thú y lâm sàng.

\section{VÂT LIÊU VÀ PHƯƠNG PHÁP NGHHẾN CÚU}

\section{1. Đối tượng nghiên cứu}

Bệnh sán lá gan nhỏ ở chó do loài Opisthorchis viverrini và Clonorchis sinensis gây ra.

\subsection{Vật liệu nghiên cứu}

Động vật thí nghiệm: 20 chó (giống chó vàng Việt Nam, 10 con đực và 10 con cái), chó được mua từ 2 tháng tuổi, khỏe mạnh, được nuôi trong phòng thí nghiệm 1 tháng. Hằng ngày xét nghiệm phân để đảm bảo không nhiễm mầm bệnh sán lá gan nhỏ.

Một số dụng cụ, hóa chất cần thiết để nghiên cứu ký sinh trùng và bệnh lý học.

Địa điểm nghiên cứu: Bộ môn Nghiên cứu Ký sinh trùng, Phân viện Thú y miền Trung.

Địa điểm làm tiêu bản bệnh lý: Phòng thí nghiệm bệnh lý, Khoa Thú y, Học viện Nông nghiệp Việt Nam.

\subsection{Phương pháp nghiên cứu}

Chuẩn bị trứng sán: Trứng sán lá gan nhỏ được thu trong túi mật chó hoặc thu thập sán trưởng thành từ chó bị bệnh trong tự nhiên (thu ở các điểm giết mổ tại các tỉnh Bình Định, Phú Yên, Khánh Hòa, Nam Định, Thái Bình và Hà Nội). Sán được đưa vào đĩa petri chứa nước cất, sán thường sống được khoảng 6 - 10 giờ sau khi tách khỏi cơ thể chó và tiểp tục thải trứng. Sau đó, trứng được ly tâm (1000 vòng/phút trong 5 phút), thu và cho vào môi trường nước tự nhiên, để ở nhiệt độ phòng thí nghiệm $\left(22-28^{\circ} \mathrm{C}\right)$ và theo dõi đến khi trứng hình thành ấu trùng (miracidium).

Gây nhiễm ốc: Trước khi gây nhiễm, ốc phải được xét nghiệm ngẫu nhiên để đảm bảo không nhiễm mầm bệnh sán lá gan nhỏ. Sau đó, ốc được cho vào chậu thủy tinh chứa nước cất. Trứng sán đã hình thành miracidium được cho vào cốc (gây nhiễm khoảng 1000 - 1200 trứng sán/100 ốc, lượng nước phải ngập các cá thể ốc). Trong thời gian gây nhiễm, chuyển ốc vào chỗ bóng tối, mỗi $15-20$ phút lắc cốc 1 lần để ốc có thể ăn được nhiều trứng sán. Sau 8 12 giờ, thả ốc xuống bể thí nghiệm. Hằng ngày, ốc được xét nghiệm bằng cách ép giữa hai tấm kính để xác định ẩu trùng sán phát triển đến giai đoạn cercaria.

Gây nhiễm cá: Khi ấu trùng phát triển đến giai đoạn cercaria và thoát ra khỏi ốc, bơi tự do trong nước thì gây nhiễm cho cá. Cá được cho vào chậu thủy tinh có chứa $500-1000 \mathrm{~mL}$ nước cất, gây nhiểm khoảng 40-50 ấu trùng/cá. Sau khi gây nhiễm, cá được thả xuống bể thí nghiệm, định kỳ mổ khám để xác định mầm bệnh phát triển đến giai đoạn metacercaria.

Phương pháp xét nghiệm cá: Được tiến hành theo từng cá thể cá bằng xem tươi (ép từng mảnh cơ dưới 2 tấm kính) và phương pháp tiêu cơ tiêu. Quan sát metacercaria dưới kính hiển vi ở độ phóng đại 100 - 400 lần. Dùng pipet thu lấy nang kén và xác định số lượng nang kén để chuẩn bị gây nhiễm.

Gây nhiễm cho chó: Cho chó nuốt nang kén sán lá gan nhỏ bằng cách dùng syringe $6 \mathrm{~mL}$ (đã bỏ đầu kim), hút dung dịch chứa 20-25 nang kén sán, đưa trực tiếp syringe qua hầu và bơm nang kén sán vào thực quản, nang kén được nuốt xuống dạ dày.

Thí nghiệm được tiến hành trên tổng số 20 chó từ 3 tháng tuổi và chia thành 2 giai đoạn thí nghiệm. Mỗi giai đoạn được bố trí thêm 3 chó không bị gây nhiễm bệnh để làm đối chứng.

Mẫu phân được thu thập, xét nghiệm bằng phương pháp lắng cặn tìm trứng sán trong phân.

Thí nghiệm được chia ra 2 giai đoạn như sau:

- Giai đoạn từ 1 đến 17 ngày: Tiến hành mổ khám 6 chó đã gây nhiễm và 3 chó đối chứng vào ngày thứ 17 khi kết thúc thí nghiệm, đây là thời gian âu trùng sán chưa phát triển đến sán trưởng thành.

- Giai đoạn từ 18 đến 40 ngày: Mổ khám 14 chó đã gây nhiễm và 3 chó đối chứng, thời gian này ấu trùng sán đã phát triển đến sán trưởng thành, sau 26 - 30 ngày sán đã đẻ trứng và trứng theo phân ra ngoài môi trường.

Tiến hành gây mê cho chó bằng thuốc Ketamin với liều $1 \mathrm{~mL} / 20 \mathrm{~kg}$ thể trọng, đợi khi chó không còn phản ứng (mê) rồi mổ khám. Động vật được mổ 
khám theo phương pháp mổ khám không toàn diện: Mổ khám bộc lộ xoang bụng, tách các cơ quan nội tạng khỏi cơ thể, quan sát bệnh tích đại thể, tìm sán ký sinh trong gan. Mẫu gan có bệnh tích đại thể điển hình được lựa chọn, bảo quản bằng cách ngâm trong formol $10 \%$ để làm tiêu bản vi thể.

Tiêu bản vi thể được làm bằng phương pháp ẩm, đúc, cắt, nhuộm Hematoxylin và Eosin; đọc kết quả trên kính hiển vi và chụp ảnh bệnh tích vi thể.
Các số liệu thu thập được trong quá trình nghiên cứu được xử lý bằng phần mềm Microsoft Excel 2010.

\section{KẾT QUẢ VÀ THẢO LUẬN}

\subsection{Triệu chứng lâm sàng chó bị bệnh sán lá gan nhỏ}

Tổng số 20 chó bị bệnh sán lá gan nhỏ trong gây nhiễm thực nghiệm, được theo dõi các biểu hiện lâm sàng sau khi gây nhiễm. Kết quả được thể hiện ở Bảng 1.

Bảng 1. Triệu chứng lâm sàng chó bị bệnh sán lá gan nhỏ

\begin{tabular}{|c|c|c|c|c|}
\hline \multirow{2}{*}{$\begin{array}{l}\text { Triệu chứng lâm } \\
\text { sàng }\end{array}$} & \multicolumn{2}{|l|}{ 1-17 ngày } & \multicolumn{2}{|l|}{ 18-40 ngày } \\
\hline & $\begin{array}{r}\text { Số con có biểu hiện/Số } \\
\text { con theo dõi }\end{array}$ & $\begin{array}{r}\text { Tỷ lệ biểu } \\
\text { hiện }(\%)\end{array}$ & $\begin{array}{r}\text { Số con có biểu hiện/Số } \\
\text { con theo dõi }\end{array}$ & $\begin{array}{r}\text { Tỷ lệ biểu } \\
\text { hiện }(\%)\end{array}$ \\
\hline Chết & $1 / 20$ & 5,0 & $2 / 14$ & 14,28 \\
\hline Táo bón & $1 / 20$ & 5,0 & $4 / 14$ & 28,57 \\
\hline Tiêu chảy & $3 / 20$ & 15,0 & $6 / 14$ & 42,85 \\
\hline Sốt, lông xù & $6 / 20$ & 30,0 & $9 / 14$ & 64,28 \\
\hline Bụng chướng & $1 / 20$ & 5,0 & $11 / 14$ & $75 / 57$ \\
\hline Mệt mỏi, giảm ăn & $4 / 20$ & 20,0 & $14 / 14$ & 100 \\
\hline Gầy yếu & $8 / 20$ & 40,0 & $14 / 14$ & 100 \\
\hline Chó đối chứng & $0 / 3$ & 0,0 & $0 / 3$ & 0,0 \\
\hline
\end{tabular}

Bảng 1 cho thấy chó bị bệnh sán lá gan nhỏ thường có một số triệu chứng lâm sàng như sốt nhẹ, lông xù, mệt mỏi, giảm ăn, gầy yếu, bụng chướng, tiêu chảy hoặc táo bón và chết. Tuy nhiên, triệu chứng lâm sàng ở chó phụ thuộc vào thời gian từ khi nhiễm mầm bệnh.

Từ khi nhiễm mầm bệnh đến ngày thứ 17 , chó có các biểu hiện như gầy yếu $(40,0 \%)$, sốt, lông xù $(30,0 \%)$, mệt mỏi, giảm ăn $(20,0 \%)$, tiêu chảy $(15,0 \%)$, bụng chướng $(5,0 \%)$, táo bón $(5,0 \%)$ và chết $(5,0 \%)$.

Sau ngày thứ 17 , các biểu hiện lâm sàng đều tăng lên so với giai đoạn trước như gầy yếu $(100 \%)$, mệt mỏi, giảm ăn $(100 \%)$, sốt, lông xù $(64,28 \%)$, bụng chướng $(75,57 \%)$, tiêu chảy $(42,85 \%)$, táo bón $(28,57 \%)$ và chết $(14,28 \%)$. Trong khi đó ở lô đối chứng, chó vẫn khỏe mạnh bình thường và không nhìn thấy dấu hiệu lâm sàng.

Hiện nay, các nghiên cứu trong nước cũng như ngoài nước về triệu chứng lâm sàng trên chó bị bệnh sán lá gan nhỏ vẫn còn rất hạn chế. Theo nhận định của Pethealth (2018) về biểu hiện lâm sàng của chó khi bị nhiễm sán lá gan nhỏ, tùy thuộc nhiều vào cường độ nhiễm và sức khỏe của vật chủ mà có thể biểu hiện nên triệu chứng khác nhau. Trong trường hợp chó nhiễm sán với số lượng ít, hầu như chó không có triệu chứng lâm sàng. Pethealth (2018) cũng nhận thấy rằng, ở giai đoạn khởi phát, chó bị mắc bệnh sán lá gan nhỏ thường bắt đầu với các biểu hiện của rối loạn tiêu hóa như chán ăn, ăn không tiêu, tiêu chảy hoặc táo bón thất thường. Ngoài ra, còn có thể nhận thấy chó toàn thân phát ban, nổi mẩn. Ở giai đoạn sau, chó thường đau vùng gan nhiều hơn, kèm theo các dấu hiệu như thiếu máu, vàng da và chướng bụng có thể xuất hiện ở giai đoạn muộn.

\subsection{Bệnh tích bệnh sán lá gan nhỏ ở chó}

Tổng số 20 chó bị bệnh sán lá gan nhỏ từ gây nhiễm thực nghiệm được mổ khám kiểm tra bệnh tích đại thể. Kết quả quan sát bệnh tích đại thể được thể hiện ở Bảng 2 và Hình 1 . 
Bảng 2. Một số bệnh tích đại thể bệnh sán lá gan nhỏ ở chó

\begin{tabular}{|c|c|c|c|c|}
\hline \multirow[b]{2}{*}{ Các biểu hiện } & \multicolumn{2}{|c|}{ 1-17 ngày } & \multicolumn{2}{|l|}{ 18-40 ngày } \\
\hline & $\begin{array}{r}\text { Số con có biểu } \\
\text { hiện/Số con mố } \\
\text { khám }\end{array}$ & $\begin{array}{l}\text { Tỷ lệ biểu } \\
\text { hiện }(\%)\end{array}$ & $\begin{array}{r}\text { Số con có biểu } \\
\text { hiện/Số con mô̂ } \\
\text { khám }\end{array}$ & $\begin{array}{r}\text { Tỷ lệ biểu } \\
\text { hiện }(\%)\end{array}$ \\
\hline Xoang bụng tích nước & $0 / 6$ & 0,0 & $5 / 14$ & 33,3 \\
\hline $\begin{array}{l}\text { Dạ dày chứa nhiều thức ăn } \\
\text { không tiêu }\end{array}$ & $1 / 6$ & 16,7 & $5 / 14$ & 35,7 \\
\hline Ruột kết viêm & $2 / 6$ & 33,3 & $5 / 14$ & 35,7 \\
\hline Xác chết gầy & $2 / 6$ & 33,3 & $6 / 14$ & 42,9 \\
\hline $\begin{array}{l}\text { Túi mật sưng lên 2-3 lần, chứa } \\
\text { nhiều trứng sán }\end{array}$ & $1 / 6$ & 16,7 & $14 / 14$ & 100 \\
\hline Gan viêm, xuất huyết & $6 / 6$ & 100 & $14 / 14$ & 100 \\
\hline $\begin{array}{l}\text { Mă̆t gan sưng, xuất hiện nhiều } \\
\text { điềm hoại tử và có nhiều sán ở } \\
\text { trong ống dẫn }\end{array}$ & $4 / 6$ & 66,7 & $14 / 14$ & 100 \\
\hline Chó đối chứng & $0 / 3$ & 0,0 & $0 / 3$ & 0,0 \\
\hline
\end{tabular}

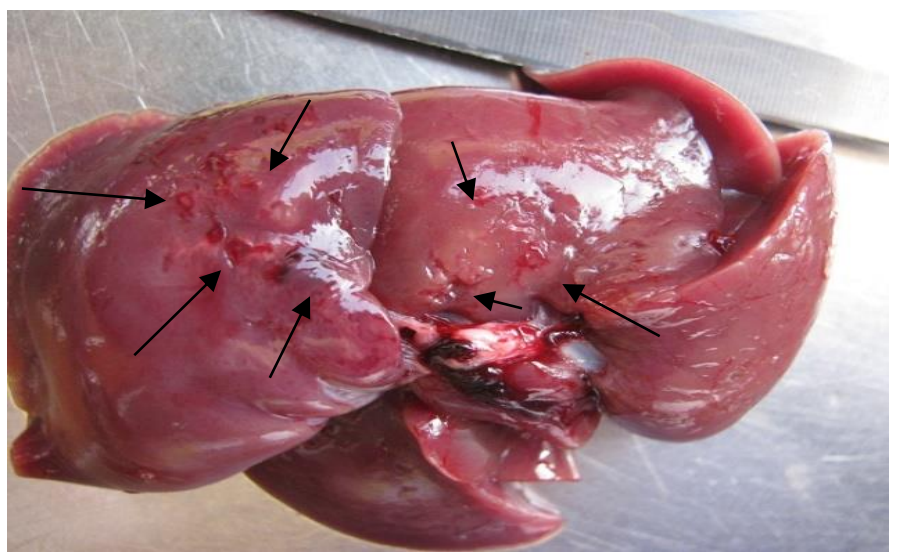

Hình 1. Bệnh tích đại thể chó bị bệnh sán lá gan nhỏ

Gan viêm, xuất huyết, có nhiều điểm màu trắng xám

Bảng 2 và Hình 1 cho thấy chó bị bệnh sán lá gan nhỏ thường có một số bệnh tích đại thể như: xác chết gầy, xoang bụng tích nước, gan viêm và xuất huyết, mặt gan sưng và có nhiều vết màu trắng xám, túi mật sưng 2-3 lần, dạ dày chứa nhiều thức ăn không tiêu, ruột kết viêm. Tuy nhiên, bệnh tích có sự khác nhau giữa các thời điểm chó nhiễ்m bệnh.

Từ khi nhiễm mầm bệnh đến ngày thứ 17,6 chó được mổ khám và phát hiện các biểu hiện như gan viêm và xuất huyêt $(100 \%)$, mặt gan sưng và có nhiều vết màu trắng xám $(66,7 \%)$, túi mật sưng $2-3$ lần $(16,7 \%)$, xác con vật gầy $(33,3 \%)$, dạ dày chứa nhiều thức ăn không tiêu $(16,7 \%)$, ruột kết viêm $(33,3 \%)$,

Sau ngày thứ 17 đến ngày 40 , mổ khám 14 chó phát hiện tỷ lệ các biểu hiện bệnh tích đều tăng lên so với giai đoạn trước như: xoang bụng tích nước $(33,3 \%)$, dạ dày chứa nhiều thức ăn không tiêu $(35,7 \%)$, ruột kết viêm $(35,7 \%)$, xác con vật gầy (42,9\%), túi mật sưng 2-3 lần (100\%), mặt gan sưng và có nhiều vết màu trắng xám $(100 \%)$.

Từ những mẫu bệnh phẩm là gan có bệnh tích đại thể, nghiên cứu để đánh giá mức độ tổn thương ở cấp độ mô bào được tiến hành. Kết quả kiểm tra mô bệnh học ở 20 mẫu gan đều phát hiện các tổn thương như gan sung huyết, hồng cầu tràn ngập lòng mạch quản, thâm nhiễm tế bào viêm, tế bào gan thoái hóa mỡ và thoái hóa không bào, tế bào gan hoại tử bắt màu hồng đều (Hình 2). Trong khi đó ở lô đối chứng, bệnh tích vi thể không tìm thấy khi mổ khám và kiểm tra mô bào. 

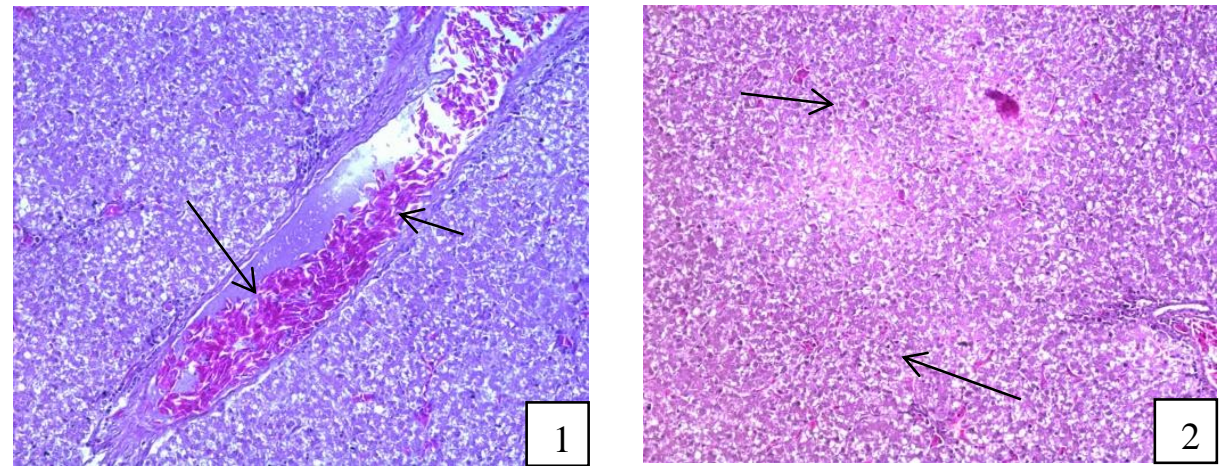

Hình 2. Bệnh tích vi thể bệnh sán lá gan nhỏ ở chó

1: Gan sung huyết, hồng cầu tràn ngập lòng mạch quản, thâm nhiếm tế bào viêm.

2: Tế bào gan thoái hóa mõ và thoái hóa không bào, tế bào gan hoại tử bắt màu hồng đều

Kết quả của nghiên cứu này đồng nhất với nghiên cứu của Lee et al. (2003), tiến hành gây nhiễm thực nghiệm cho chó bằng nang kén sán lá gan nhỏ, sau đó mổ khám và kiểm tra mô bệnh học. Kết quả cho thấy có sự tăng sinh và phì đại của các động mạch trong khu vực ống thông và các đường tĩnh mạch cửa gan; sự tắc nghẽn của các mạch quản trong gan khi gan nhiễm sán với số lượng nhiều. Thoái hóa và hoại tử các tế bào biểu mô ở gan.

Đến nay, vẫn còn ít nghiên cứu về bệnh lý bệnh sán lá gan nhỏ ở chó vẫn còn ít. Tuy nhiên, theo tài liệu của Trung tâm Phòng chống bệnh (Centers for Disease Control and Prevention, 2018), cơ bản giống với nhận định của nghiên cứu này. Tài liệu cho thấy các triệu chứng lâm sàng chỉ nghiêm trọng khi con vật bị bệnh kéo dài, các bệnh lý chủ yếu là do viêm và tắc nghẽn từng đợt của đường mật, với các biểu hiện như: Khó tiêu, đau bụng, tiêu chảy hoặc táo bón, con vật sốt, gan to và suy dinh dưỡng...

\section{KẾT LUẬN}

Chó bị bệnh sán lá gan nhỏ với các triệu chứng lâm sàng như: sốt nhẹ, lông xù, mệt mỏi, giảm ăn, gầy yếu, bụng chướng, tiêu chảy hoặc táo bón và chết. Bệnh tích đại thể: xác con vật gầy, xoang bụng tích nước, gan viêm và xuất huyết, mặt gan sưng và có nhiều vết màu trắng xám, túi mật sưng 2-3 lần, dạ dày chứa nhiều thức ăn không tiêu, ruột kết viêm. Bệnh tích vi thể: gan sung huyết, hồng cầu tràn ngập lòng mạch quản, thâm nhiễm tế bào viêm, tế bào gan thoái hóa mỡ và thoái hóa không bào, tế bào gan hoại tử bắt màu hồng đều.

\section{TÀI LIỆU THAM KHẢO}

Bùi Văn Tuấn, Lý Chanh Ty, Huỳnh Thị Thanh Xuân, Trần Ngọc Thảo \& Nguyễn Hải Khánh. (2017). Nghiên cứu thành phần loài sán lá gan nhỏ truyền qua cá nước ngọt ký sinh trên người tại một số tỉnh miền Trung-Tây Nguyên. Tạp chi Phòng chống bệnh sốt rét và Các bệnh ký sinh trùng, Bản đặc biệt (96), 181-187.

Centers for Disease Control and Prevention. (2018, February 20). Opisthorchiasis. https://www.cdc.gov/dpdx/opisthorchiasis/index. html

Havelaar, A.H., Kirk, M.D., Torgerson, P.R., Gibb, H.J., Hald, T., Lake, R.J., Praet, N., Bellinger, D.C., De Silva, N.R., \& Gargouri, N. (2015). World Health Organization global estimates and regional comparisons of the burden of foodborne disease in 2010. PLoS medicine, 12(12), 1-23. DOI: 10.1371/journal.pmed.1001923

Lee, K.H., Hong, S.T., Han, J.K., Yoon, C.J., Lee, S., Kim, S.H., \& Choi, B.I. (2003). Experimental clonorchiasis in dogs: CT findings before and after treatment. Radiology, 228(1), 131-138.

Nguyễn Mạnh Hùng, Trần Thanh Dương \& Nguyễn Thu Hương. (2013). Tình hình nhiêm giun sán đuờng ruột tại 4 tỉnh Nghệ An, Thanh Hóa, Hòa Bình và Bắc Giang. Hội nghị khoa học - Đào tạo chuyên ngành Ký sinh trùng toàn quốc lần thứ 41, Viện Sốt rét - Ký sinh trùng - Côn trùng TW, 11-18.

Nguyễn Văn Chương, Bùi Văn Tuấn, Triệu Nguyên Trung \& Nguyễn Văn Khá. (2009). Tình hình nhiễm sán lá gan nhỏ Opisthorchis viverrini sau thời gian can thiệp tại 2 tỉnh Phú Yên, Bình Định. Tạp chi phòng chống bệnh sốt rét và các bệnh ký sinh trùng, 833-878. 
Nguyễn Văn Đề \& Lê Thanh Hòa. (2007). Tình hình nhiếm sán lá gan ở người và thành phần loài sán lá gan ở Việt Nam. Kỷ yếu công trình nghiên cứu khoa học 2001-2006, Viện sốt rét-Ký sinh Trùng-Côn Trùng Quy Nhơn. NXB Y học Hà Nội, 474-482.

Pethealth. (30-12-2018). Biển hiện bệnh sán lá gan nhỏ ớ chó | kiến thức tù Pethealth.

https://pethealth.vn/bieu-hien-benh-san-la-gannho-o-cho/
Tran, A.K.T., Doan, H.T., Do, A.N., Nguyen, V.T., Hoang, S.X., Le, H.T.T., Hoang, H.T., Le, N.H., Le, Q.B.T., \& Le, T.A. (2019). Prevalence, species distribution, and related factors of fishborne trematode infection in Ninh Binh province, Vietnam. BioMed research international, 2019, 1-8. DOI: $10.1155 / 2019 / 8581379$. 